\title{
EHMTI-0175. Analysis of migraine among Nepalese population: classification, triggering factors, prophylactic and abortive treatment
}

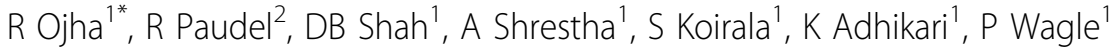 \\ From 4th European Headache and Migraine Trust International Congress: EHMTIC 2014 \\ Copenhagen, Denmark. 18-21 September 2014
}

\section{Introduction}

Migraine is a chronic neurological disease that is disabling to most of the patients. Although migraine is very common, only a few studies have been reported from Nepal.

\section{Aims}

This study was conducted to understand the characteristics of migraine among Nepalese population.

\section{Methods}

We retrospectively studied migraine patients presented in Neurology outpatient department of Grande International Hospital and Bir Hospital, Kathmandu, Nepal between August 2013 and March 2014.

\section{Results}

A total of 187 migraine patients were included in the study (Grande International Hospital: 138 patients; Bir Hospital: 49 patients). Mean age of the patients was 35.93 \pm 13.22 years (range: 8-73 years) with female patients: 147 (78.6\%) and male patients: 40 (21.4\%). Migraine without aura (73.3\%), Migraine with aura (16.0\%) and vertebrobasilar migraine $(7.5 \%)$ are the common migraine types. Thirty-three patients (17.6\%) presented as chronic daily headache and 2 patients (1.1\%) presented as status migrainosus. Divalproex was the most commonly used as prophylactic treatment $(31.0 \%$, followed by propranolol (17.1\%) and amitriptyline (17.1\%). No prophylactic treatment needed for 37 patients (19.8\%), whereas 5 patients (26.7\%) needed 2 drugs combination for better control of migraine attacks. Sumatriptan was most commonly used for abortive treatment (89.3\%). Sunlight or hot

${ }^{1}$ Neurology, National Academy of Medical Sciences Bir Hospital, Kathmandu, Nepal

Full list of author information is available at the end of the article environment was the most common triggering factor (30 patients; 16\%).

\section{Conclusions}

Prophylactic medications have a good control over migraine attacks. Avoidance of trigger may further help in the proper management of migraine. Government should further focus on public awareness programs regarding diagnosis and management of migraine in rural areas of Nepal.

No conflict of interest.

\section{Authors' details}

${ }^{1}$ Neurology, National Academy of Medical Sciences Bir Hospital, Kathmandu, Nepal. ${ }^{2}$ Neuroscience, Grande International Hospital, Kathmandu, Nepal.

Published: 18 September 2014

doi:10.1186/1129-2377-15-S1-G28

Cite this article as: Ojha et al:: EHMTI-0175. Analysis of migraine among Nepalese population: classification, triggering factors, prophylactic and abortive treatment. The Journal of Headache and Pain 2014 15(Suppl 1):G28.

Submit your manuscript to a SpringerOpen ${ }^{\bullet}$ journal and benefit from:

- Convenient online submission

- Rigorous peer review

- Immediate publication on acceptance

- Open access: articles freely available online

- High visibility within the field

- Retaining the copyright to your article

Submit your next manuscript at $\gg$ springeropen.com
(C) 2014 Ojha et al; licensee Springer. This is an Open Access article distributed under the terms of the Creative Commons Attribution License (http://creativecommons.org/licenses/by/2.0), which permits unrestricted use, distribution, and reproduction in any medium, provided the original work is properly cited. 